\title{
The Aesthetics of Internationalism: Culture and Politics on Display at the 1935-I936 International Exhibition of Chinese Art ${ }^{*}$
}

\author{
ILARIA SCAGLIA \\ Columbus State University
}

$\mathrm{B}$ ETween November 1935 and March 1936, nearly 422,000 visitors entered Burlington House, the luxurious home of the Royal Academy in Piccadilly, in the heart of London. ${ }^{1}$ They came to admire the International Exhibition of Chinese Art, a show featuring more than three thousand Chinese objects lent by numerous individuals, institutions, and governments. Indeed, this was "the largest Chinese cultural event ever mounted," a must-see. ${ }^{2}$ Letters asking for extensions to view-

* I would like to thank Stefania Benini, Sarah Bowman Daniel Crosswell, Andreas Daum, Danielle Fosler-Lussier, Steven Gill, Daniel Gullo, and Georg and Wilma Iggers for reading and providing me with feedback on this article.

1 According to the Royal Academy's Annual Report, 40I,768 paying visitors walked trough the turnstiles of Burlington House, and 2,53 I season tickets were sold. Annual Report from the Council of the Royal Academy to the General Assembly of Academicians and Associates for the Year 1936 (London: William Clowes and Sons, 1937), 23, 40. The figure of more than 422,000 , widely reported by the press, included private viewings and nonpaying visitors. This number placed the Chinese exhibition second only to the I930 Italian exhibition, which attracted 537,968 people. As a term of comparison, the 1927 Exhibition of Flemish and Belgian Art totaled I5I,806 paying visitors; the 1929 Dutch exhibition, 230,400; the I93 I Persian, 255,724; and the I932 French exhibition sold 298,20I single tickets and 5,444 season tickets. I thank Mark Pomeroy, archivist of the London Royal Academy, for providing me with these figures from the institution's internal database.

2 Jason Steuber, "The Exhibition of Chinese Art at Burlington House, London, I93536," Burlington Magazine I 48, no. I24I (2006): 528. 
ing times filled the academy's mailbox, and concerns arose about safety to the point that the doors had to be closed to prevent overcrowding. Newspapers around the world reported that during the last day of the opening, the atmosphere was nearly hysterical: "As late as ten minutes before closing the enthusiasts rode up in taxis to catch a glimpse of a few rare exhibits," while "thousands lingered sadly to bid farewell to all the beauty which had delighted London for three months." ${ }^{3}$ Decades later, this exhibition would be remembered and studied as a "pivotal event" that raised an unprecedented degree of interest in Chinese art and culture. ${ }^{4}$

One reason for this success was the extraordinary collection of objects on display. ${ }^{5}$ In the first room, visitors were welcomed by an assemblage of recently excavated pieces from the prehistoric village of Yangshao, in Henan. Next was a breathtaking array of Shang and Zhou bronzes, which the Chinese government had allowed outside of the country especially for the occasion. Numerous works from the Han period and a wide assortment of early Buddhist sculptures followed. Then came artifacts from the Wei and the Tang dynasties, with paintings from Dunhuang in the background. Rooms 4-6 carried hundreds of vases, dishes, and porcelains dramatically set against a backdrop of Tang and Song paintings, some lent by the Chinese government, others by Japanese collectors. Room 7 housed more bowls and vases, which illustrated the shift from the Song to the Mongol Yuan dynasty. Then, in successive rooms were Ming vases, with their familiar white and blue patterns, and seventeenth- and eighteenth-century lacquers. The most recent productions-mostly from the late eighteenth century-were located in the South Room, next to a small niche containing a selec-

3 The Times, 3 March 1936; Jersey Evening Post, 9 March 1936; Shanghai Times, 27 March 1936.

${ }^{4}$ Steuber, "The Exhibition of Chinese Art," 536. Historians have unanimously recognized that this show scored an unprecedented success and provided a great stimulus to the study of Asia, and of China in particular. This exhibition later became a benchmark for evaluating all the others that followed it. For instance, when commenting on the landmark I96I Chinese traveling exhibition in the United States, Warren Cohen noticed how its impact "was almost as great as that of the original Burlington House show." Warren I. Cohen, East Asian Art and American Culture: A Study in American Relations (New York: Columbia University Press, I992), I46.

${ }^{5}$ Since a description of individual works of art is not central to the argument, I provide here only a brief sketch of the content of the exhibition. For a complete list of the works exhibited (accompanied by a detailed roster of individual lenders) see Catalogue of the International Exhibition of Chinese Art, I935-1936 (London: Royal Academy of Arts, I935), and The Chinese Exhibition: A Commemorative Catalogue of the International Exhibition of Chinese Art, Royal Academy of Arts November 1935-March 1936 (London: Faber and Faber, 1936). 
tion of Chinese books and calligraphy. Finally, in the Central Hall, at the heart of the academy, a monumental sculpture of Amitābha Buddha watched over the thousands who came to admire it. This piece was surrounded by loans from the queen and king of England, the Chinese government, and the Japanese imperial household. Virtually every art and craft ever produced in China was represented within the confines of Burlington House.

However, the most distinctive feature of this event was its international-and internationalist—aspect, as the exhibition showcased not only works of art but also the people, the institutions, and the internationalist policies that had led to their preservation and display. ${ }^{6} \mathrm{I}$ use the term "internationalism" here to refer to a complex set of ideas and practices at times in contradiction with one another. At its core was what Glenda Sluga called "twentieth-century internationalism," a realist policy based on the acceptance of the principle of nationaland even racial-difference. Nations existed and their rights had to be protected, and for peace to be maintained, the conditions had to be created for them to interact with one another in a peaceful manner. The quintessence of this form of internationalism was the League of Nations and its attached bodies, which were created to facilitate this exchange by gathering representatives from all member states. ${ }^{7}$ Thus, "twentieth-century internationalism" was starkly distinct from "proletarian internationalism," "revolutionary internationalism," and other pacifist movements that were antithetical to nationalism. Nevertheless, as this study demonstrates, it adopted their languages, incorporating universalist arguments about the need to transcend national and racial borders, anti-modernist rhetoric, and widespread critiques of the capitalist system, and revolutionary calls for the need to emancipate all peoples from the powers that oppressed them. The result was a complex ideology, not to be merely associated with pacifism, idealism, and benevolent intentions but to be understood instead-using Grace Brockington's words - as "a floating category, compatible with

${ }^{6}$ The political aspect of this exhibition has been examined in the context of nationalism but not as part of the history of international cooperation. Jason Steuber interpreted the exhibition as a nationalistic endeavor, while Ellen Huang stressed the polarizing nature of this event. Warren Cohen noticed the importance of the 1935-1936 exhibition in the context of cultural diplomacy, but given the American focus and the larger chronological scope of his book he dedicated only a few pages to it. See Cohen, East Asian Art and American Culture, I22-I 25.

7 Glenda Sluga, Internationalism in the Age of Nationalism (Philadelphia: University of Pennsylvania Press, 2013), 5. 
reactionary and racist politics, as well as with the left-wing and progressive." If the interwar period was a time of "twisted paths," to borrow Robert Gerwarth's useful metaphor, then internationalism crossed all of them. ${ }^{9}$

This study argues that the 1935-1936 International Exhibition of Chinese Art in London represented the visible implementation of this form of internationalism in all its complexity. While previous shows had included objects that European-and sometimes American-collectors had brought back from China, this exhibition was organized jointly by both the British and the Chinese governments, and featured as its centerpiece the imperial collection of the Beijing Palace which the Chinese government had sent especially for this occasion. ${ }^{10}$ Burlington House therefore served as a symbolic Palais des Nations, a place where people from various countries gathered to celebrate the Chinese cultural tradition as well as the Republic of China as its rightful heir. This particular event was also the first to be truly global in scope, as a large number of people and institutions from numerous countries around the world lent pieces for the exhibition. In the midst of increasing international tensions, the fact that many countries (including Germany and Japan) participated in the event reinforced the idea that art was put to work to foster mutual understanding and peace in an internationalist context. Moreover, for this occasion Chinese artifacts served as tokens of political goodwill that represented a country's willingness to engage in international exchange and cooperation. At a time when the League of Nations encouraged the exchange of works of art across borders as a way to promote peaceful relations among nations, participating in this exhibition symbolized support for the League's policies. Finally, in the post-I9I9 world, the use of the term "international" in the title of the

\footnotetext{
${ }^{8}$ Grace Brockington, Internationalism and the Arts in Britain and Europe at the Fin de Siècle (New York: Peter Lang, 2009), 22. As many scholars have demonstrated in the last twenty years, internationalism was one of the major "Isms" of the twentieth century, supranational institutions such as the League of Nations played an important role, and transnational connections (exchanges among non-state actors, or individuals and institutions outside of government) constituted an integral part of internationalist ideas, institutions, and practices. See, for instance, Daniel Laqua, ed., Internationalism Reconfigured: Transnational Ideas and Movements between the World Wars (New York: Palgrave Macmillan, 20 I I).

${ }^{9}$ Robert Gerwarth, ed., Twisted Paths: Europe 19I 4-I945 (Oxford: Oxford University Press, 2007).

${ }^{10}$ For details on the Chinese loans, see Ellen Huang, "There and Back Again: Material Objects at the First International Exhibition of Chinese Art in Shanghai, London, and Nanjing, I935-1936," in Collecting China: The World, China, and a History of Collecting, ed. Vimalin Rujivacharakul (Newark: University of Delaware Press, 20I I), I38-I52.
} 
exhibition evoked internationalist discourses of this period and represented the internationalist principles that were emerging at this time. As an adjective that defined the whole, "international" expressed that in essence this exhibition was about the cooperation that had inspired it and made it possible.

From a chronological point of view, the mid I 930 s have been widely examined in the history of nationalism but have received little attention in terms of their importance in the development of internationalism worldwide. ${ }^{11}$ Yet the mid I93os constituted an essential moment for the shaping of the "aesthetics of internationalism," a set of images and performances through which internationalism was defined and disseminated. This study explores this crucial development by focusing on the role played by art and international cultural events in determining what international cooperation looked like in the interwar period. The spotlight is on what was placed overtly on display. To be sure, many of the actors involved in this exhibition had ulterior motives: individual collectors and institutions often sought to strengthen their own profile; and all the governments involved used this cultural event—and its rhetoric of internationalism - to further nationalistic or imperialistic aims, or to propose alternatives to the existing order in their own countries as well as on a global scale. Yet most relevant here are the rhetoric and the practice of international cooperation. The fact that these might have served as a guise for pursuing other agendas does not change the fact that international cooperation existed in this period and was made visible to all. Internationalism, as Mark Mazower pointed out, had an "energy" that derived from the ideals on which it was based and that was vital to its existence. It was thanks to this energy that it continued to attract support for years to come. It is in this setting, therefore, that the cultural event examined in this article becomes meaningful, as it had at once originated from and fueled this energy. As a concrete and visible practice of international cooperation, it represented its strongest endorsement and saw to its endurance. ${ }^{12}$

In recent years, much attention has been paid to the relationship

${ }_{11}$ Most works focused either on the nineteenth century or on the period spanning from the "Wilsonian moment" to the establishment of the League. Among the authors who have pointed out the importance of internationalism in the I93os is Patricia Clavin, "Introduction: Conceptualising Internationalism between the World Wars," in Laqua, ed., Internationalism Reconfigured, I-I4.

12 Mark Mazower, No Enchanted Palace: The End of Empire and the Ideological Origins of the United Nations (Princeton, N.J.: Princeton University Press, 2009), 6-7, I3. 
between politics and aesthetics in the twentieth century, and to the part that performances, spectacles, and displays played in influencing not only the dissemination but also the definition of political ideologies. ${ }^{13}$ However this "aesthetic turn," as Ronald Bleiker has called it, has centered on "repressive regimes" (e.g., the study of various forms of nationalism and empire), thus leaving internationalism out of the picture. ${ }^{14}$ But, as this study shows, performances, spectacles, and displays affected internationalist ideas and practices as well. If nationalism was made - and made itself — through its aesthetic experience, the same was true for internationalism. ${ }^{15}$ In this context, art (not only its production but also its study, preservation, exchange, and display) and international art exhibitions provided an aesthetic vocabulary that defined what internationalism looked like to the public eye. In an age of mass communication, logistical tasks acquired a performative function: acts such as transporting and unpacking artifacts were carefully documented and widely publicized, they became carefully staged, and assumed a high symbolic value. The cultural events themselves increasingly showcased the internationalist actors, ideas, and policies behind their display. Long lists of lenders, sponsors, and executive and honorary committees found their way into official catalogues, and references to the goodwill that had led to the staging of these events occupied many pages in a growing number of publications. Here, images - defined as real and metaphorical visual representations, which were extensively reproduced in print, photographs, and newsreels-became increasingly important. Photographs of people from various backgrounds working together toward the common goal of exhibiting works of art-or the visible safety measures put in place to ensure their protection-became associated with international cooperation and internationalism. It was in the I930s, at events such as the one examined in this study, that these images were inaugurated

${ }_{13}$ Recent reflections on politics and aesthetics include Roland Bleiker, Aesthetics and World Politics (New York: Palgrave Macmillan, 2009), and Michael Lane Bruner, Repressive Regimes, Aesthetic States, and Arts of Resistance (New York: Peter Lang, 201 2). In her groundbreaking work, Nadine Rossol convincingly argued that the use of aesthetics for political purposes was not invented by or limited to the Nazi regime. Nadine Rossol, Performing the Nation in Interwar Germany: Sport, Spectacle and Political Symbolism, 1926-36 (New York: Palgrave Macmillan, 2010). On "politics of visibility" as politics of inclusion see Andreas Daum, Kennedy in Berlin, trans. Dona Geyer (New York: Cambridge University Press, 2008).

${ }^{14}$ Bleiker, Aesthetics and World Politics, I 9.

15 On the aesthetic aspect of fascism see Simonetta Falasca-Zamponi, Fascist Spectacle: The Aesthetics of Power in Mussolini's Italy (Berkeley: University of California Press, I997). 
and tested, providing internationalism with a defined set of symbolic aesthetic representations. ${ }^{16}$

During the I930s, Chinese art fit particularly well into the aesthetic vocabulary of internationalism while enhancing it at the same time. The young Republic of China was a strong supporter of the League and its policies. Especially after the Manchurian crisis of I93 I, when it did not take unilateral action against Japan but relied on the League of Nations and on the international community as a whole to settle the issue, the Republic of China epitomized commitment to the internationalist project. As a result, Chinese cultural production came to symbolize adherence to internationalism. Moreover, the academic fields of collection, preservation, study, exchange, and display of Chinese art were already very international in the I930s, as they included scholars from all parts of the world. This international aspect, which had largely derived from imperialist practices, was now reinterpreted as an example of concrete implementation of internationalist principles. While the Chinese Nationalist government was pursuing a policy of "openness" and the Committee of Intellectual Cooperation of the League of Nations promoted "technical cooperation" across borders, the image of Chinese and non-Chinese experts working together spoke of the success of the internationalist model.

Here, orientalist ideas and practices of constructing "China," its past, its culture, and its people, as the "other" acquired a new complexity. If old exoticisms and stereotypes continued to exist and underlined all relations between "East" and "West," new formulations now accompanied them, as "China" increasingly served as an imaginary space to express a wide variety of criticisms and dissatisfactions. ${ }^{17}$ As this study shows, for people such as the English poet Lawrence Binyon, Chinese

16 As art historian Keith Holz has pointed out, the notion that "the exhibition of one nation's art to another could improve the relationship between the two countries" cannot be overlooked, since it constituted the "fundamental and guiding assumption to underpin officially sponsored art exhibitions sent abroad between European countries during the thirties." Keith Holz, Modern German Art for Thirties Paris, Prague, and London (Ann Arbor: University of Michigan Press, 2004), I 43. Yet this notion has never been analyzed in depth in an academic work, and the same art historian rapidly discounted it as a "wish-laden" hope, a set of ideas based on I93os assumptions whose "banality" is self-evident. Holz, Modern German Art, I43, I45-I46.

17 On the problem of modernity in the Asian context see Harry Harootunian, ed., Overcome by Modernity: History, Culture, and Community in Interwar Japan (Princeton, N.J.: Princeton University Press, 2000). I see the same dynamics connecting modernity with fascism at play in the shaping of internationalism as well. 
art made one realize "the place of man in an infinitely complex universe" while leaving "no room for our small greed and self-aggrandizement." 18 The well-established orientalist image of China as a calm and timeless place acquired a political dimension, as it served now as a tool for self-reflection and even criticism of "Western" values and policies in the interwar period. Moreover, at a time when it was introduced to the world in the international arena, Chinese art offered an aesthetic experience of what international cooperation and internationalism could achieve in the post-19I9 world, and spoke the entrancing idiom of peace and unity to which internationalism owed its appeal. As a multifaceted, constructed entity, the aesthetics of Chinese art-and the emotions they triggered-fed into the growing visual vocabulary of internationalism and thus served as a window onto all its complexities and contradictions.

\section{The Chinese Exhibition as a Display} of "Twentieth-Century Internationalism"

The few scholars who have studied the I935-1936 International Exhibition of Chinese Art in London have interpreted it as a moment of nationalist publicity. Jason Steuber, in an article published in Burlington Magazine in 2006, pointed out how this cultural event was an example of the sapient use of "art and propaganda" in the age of nationalism. ${ }^{19}$ The late art historian Francis Haskell, when discussing the series of exhibitions that peaked with the Chinese show, also emphasized how "the mounting of Old Master exhibitions to flaunt national prestige was already a well-established custom," and this specific series expanded it to an unprecedented degree. ${ }^{20}$ Most recently, Ellen Huang looked at the "exchanges," "dialogues," and "discourses" that developed during the exhibition as a contest between two diametrically opposed sides (China and Great Britain), which she defined by the binaries colonized-colonizer, East and West. ${ }^{21}$ Yet the $1935-1936$

18 "Luncheon in Honour of the Chinese Art Exhibition," Journal of the Royal Central Asian Society 23 (January 1936): 96.

19 Steuber, "The Exhibition of Chinese Art," 535.

${ }^{20}$ Francis Haskell, "Botticelli, Fascism and Burlington House-The 'Italian Exhibition' of I 930," Burlington Magazine I4 I, no. I I 57 ( I 999): 472.

${ }^{21}$ Huang's article provides an excellent overview of Chinese sources and a detailed account of the exhibition from the Chinese perspective. See Huang, "There and Back Again," I38-152. 
International Exhibition of Chinese Art in London was not merely a piece of nationalistic propaganda but rather an overt public display of various internationalist ideas and practices that were developing on a global scale in this period.

From the moment in which it was conceived, the 1935-1936 International Exhibition of Chinese Art represented a celebration of "twentieth-century internationalism." Mirroring the League's rhetoric, ideas, and practices, this cultural event celebrated the artistic tradition of one nation-state- the Republic of China as the heir to the Chinese past-by bringing together the British and the Chinese governments, as well as individuals and institutions from many other countries. This event celebrated the achievement of a harmonious balance between national and international interests: It was a moment of concrete encounter in which peoples and nations would maintain their individual identities while engaging in peaceful and cordial exchanges with one another.

As part of the League's project, transnational (or non-state) actors such as individuals, networks, and nongovernmental institutions were woven into the fabric of international cooperation. For this reason, the League included large sections dealing with "functional cooperation" in fields as diverse as health, communication, infrastructure, and culture. In all of these cases, the goal was to facilitate exchanges outside of intragovernmental interactions. In this light, the 1935-1936 Chinese exhibition represented a prime example of internationalism, as it involved an unprecedented number of transnational actors (art institutions, museums, and individual collectors) who were active across borders and who for the first time collaborated with national authorities to celebrate one country's artistic tradition..$^{22}$

22 In their seminal work Transnational Relations and World Politics, published in I97I, political scientists Joseph S. Nye and Robert O. Keohane defined a "transnational relationship" as "one where at least one of the partners is a non-national actor." As a consequence, nongovernmental organizations (NGOs) —along with the communities revolving around them-became primary subjects of transnational studies. In later years, a broader meaning has been attributed to the term "transnational" to include not only relations between non-state actors but also the mutual effects and implications of contacts between "cultures." In recent years, the term "transnational" has also been used in connection to "networks" and "communities," and to their roles in shaping international relations. See Patricia Clavin, "Defining Transnationalism," Contemporary European History I4, no. 4 (2005): $42 \mathrm{I}-439$. Based on this literature, I use the term "transnational" to qualify people and institutions who were not directly connected to their governments and whose activities spanned across borders (e.g., scholars, art collectors, and museums). 
The number of national and transnational actors involved in the Chinese exhibition was by all accounts impressive. The idea for this show originated in Great Britain from a heterogeneous group of people interested in Chinese art: financier and collector Sir Percival David; magnate, collector, and co-founder of the Oriental Ceramic Society George Eumorfopoulos; Sir George Hill and Robert Hobson, the director and the keeper of oriental antiquities of the British Museum, respectively; and retired major general of the British army Sir Neill Malcolm. These five individuals contacted the British Foreign Office in 1934 asking for "support and patronage" for the idea of a major Chinese exhibition in London. Without the involvement of both the British and the Chinese governments, they insisted, their project could not become a reality. ${ }^{23}$

Both the British Foreign Office and the Chinese Ministry of Education quickly approved the plan, and a larger organizing committee was expanded to include diplomat and League of Nations representative Victor Bulwer-Lytton (chairman); the Chinese ambassador in London, Guo Taiqi; the president of the London Royal Academy, Sir William Llewellyn (vice-chairman); F. T. Cheng (special commissioner of the Chinese government); W. R. M. Lamb (secretary); and F. J. P. Richter (secretary of the Lecture Committee). Other members included a select group of artists and people interested in Chinese art. ${ }^{24}$ In China, a "Planning and Preparatory Committee" was soon set up to coordinate the loan of the objects from the imperial collection. At its head was the Chinese minister of education, Wang Shijie. Other members included several representatives of the

${ }^{23} \mathrm{FO} 370 / 452$, L 308/308/405. Letter, dated I4 January 1934, from Major General Neill Malcolm to Charles Orde. See also "Draft of a Memorandum on an International Exhibition of Chinese Art in London," attached to FO 370/452, L 516/308/405; and RAA/ SEC/24/25/I, "Memorandum on an International Exhibition of Chinese Art in London," dated 3 February 1934, signed by Sir George Hill, Sir Neill Malcolm, Sir Percival David, Mr. George Eumorfopoulos, and Mr. R. L. Hobson.

${ }^{24}$ These were the scholar and curator of the Victoria and Albert Museum Leigh Ashton; poet, art historian, and curator of the British Museum Laurence Binyon; Dr. W. C. Chen of the Chinese embassy; museum philanthropist Dr. J. S. Lee (also known as Bei Shan Tang); the academy's treasurer, painter Sydney Lee; Victoria and Albert Museum curator Bernard Rackham; art collector Oscar Raphael; young Chinese artist and collector C. C. Wang; and Professor Perceval Yetts. Finally, the renowned French Sinologist Paul Pelliot was engaged as a consultant for the selection of the objects to be put on display. Annual Report from the Council of the Royal Academy to the General Assembly of Academicians and Associates for the Year 1934 (William Clowes and Sons, limited, Printers to the Royal Academy, 1935), I9-20. See also Press Announcement (January 1935) RAA/SEC/24/25/I. 
major branches of government, as well as the renowned artist and poet Chen Shuren. In addition, there were executives from the most prestigious Chinese cultural institutions: Ma Heng, who served as director of the Palace Museum, and Yuan Tongli, the president of the National Library of Peiping. ${ }^{25}$ Furthermore, a distinguished group of lecturers was invited to address the public on subjects related to the Chinese exhibition. This included several members of the British and the Chinese committees, along with famous Sinologists, archaeologists, and scholars from various countries around the world (most notably, Langdon Warner from the United States and Yukio Yashiro from Japan). Finally, the roster of organizers included a long list of generous sponsors and honorary members who offered auspices for the occasion. Indeed, if twentieth-century internationalism was the idea and the practice of gathering a wide range of both state and non-state actors, each distinguished by nationality and yet committed to a common goal, then the 1935-1936 International Exhibition of Chinese Art represented one of its most overt displays.

\section{Tasks Turned into Performance:}

International Cooperation Made Visible to the Public

Much of the staging process for the 1935-1936 International Exhibition of Chinese Art in London was conducted publicly. Essential tasks such as transporting or unpacking the objects to be exhibited were completed while taking into account not only their pragmatic but also their performative function. Pictures and newsreels were shot while tending to these tasks. These moments were widely published, and arguably attracted as much attention as the exhibition itself. It is important to note here that at this time the League of Nations, and the Institute of Intellectual Cooperation in particular, promoted the development of "practical cooperation" among experts from various nations. ${ }^{26}$ The idea was to create a tauter canvas of relations that would make it less likely for peoples and countries to go to war against one another. In

${ }^{25}$ For further details, see RAA/SEC/24/25/I, Telegram, dated i 2 December 1934, from Wang Shih-chieh (Minister of Education). See also the aforementioned article by Ellen Huang.

${ }^{26}$ On the history of intellectual cooperation see Jean-Jacques Renoliet, L'Unesco oubliée: La Société des nations et la coopération intellectuelle, 1919-1946 (Paris: Publications de la Sorbonne, 1999). 
this context, the transportation of the objects and the unpacking and mounting of the 1935-1936 exhibition illustrate well how this event showcased not only works of art but also-and more overtly-internationalist ideas and policies. By being conducted in public, these tasks turned into a performance, a display of international cooperation in a concrete setting.

The transportation of the works of art that the Nanjing government sent to London for the 1935-1936 exhibition was carefully staged to celebrate the international cooperation that had made the event possible. The organizers took care of every detail of this display. Strikingly, they paid relatively little attention to other-arguably weightier-matters. For instance, to keep the cost down, the works of art from China were not insured. Instead, most energy was devoted to ensuring that the transportation of the objects from China to Britain would display and celebrate internationalist policies, as well as those who pursued them. ${ }^{27}$

The Nationalist regime in China used the transportation of the objects as a moment to reinforce its own position in China and to address domestic criticism of its internationalist policy. During the so-called Nanjing decade (1927-1937), General Chiang Kai-shek led an effort to centralize state control and to reduce foreign domination. The invitation to participate in the organization and the staging of the Chinese exhibition in London afforded Chiang's regime a good opportunity to demonstrate - and possibly enhance-its authority over China's national treasures. If the Nanjing government could choose what, when, where, and how Chinese artifacts would be displayed, it would advance its claims to rule the entire Chinese territory, including the contested northeast. More importantly, the exhibition provided the Nationalist regime with the opportunity to use Chinese works of art as symbolic tokens of its willingness to collaborate with other nations. As Rebecca Karl pointed out, an "understanding of globality as a shared historical condition on a shared world stage" had been central to the emergence of nationalism in China, had shaped its discursive formations, and had made the Chinese visualize the world as an international arena. ${ }^{28}$ In this context, the Nationalist government sought to

${ }^{27} \mathrm{FO} 370 / 452, \mathrm{~L} 6779 / 308 / 405$. Aide-memoire, dated I 3 November 1934, from the Chinese legation in London to the Foreign Office. See also FO 370/452, L 667I/308/405. Telegram, dated i I November 1934, from Alexander Cadogan to the Foreign Office.

${ }^{28}$ Rebecca Karl, Staging the World: Chinese Nationalism at the Turn of the Twentieth Century (Durham, N.C.: Duke University Press, 2002), 195-196. 
lift China up from the semicolonial status to which it had been reduced in the nineteenth century by negotiating with the very powers that still exploited it on issues such as tariff autonomy and extraterritoriality. ${ }^{29}$ In dealing with Japan, the regime also trusted the international community and the League of Nations to intervene in order to avoid another conflict. Participating in the 1935-1936 exhibition in London fell in line with the route of "openness," international negotiation, and engagement with which the Nationalist regime sought to improve China's place in the international arena, and therefore strengthened the Nationalist regime that pursued it. ${ }^{30}$

In turn, the British Foreign Office used the 1935-1936 Chinese exhibition to foster its policy in Asia. Determining what this policy should be, however, was no easy task. There were two competing views on how to deal with the complex situation in the "Far East." On one side, there were those who advocated the strategy of defending British interests in East Asia by cultivating a special relationship with Japan. Several members of the treasury, and Chancellor of the Exchequer Neville Chamberlain in particular, believed that by entrusting Japan with the defense of mutual interests in the Pacific, Great Britain could free some of its military forces and strengthen its own defenses in Europe. The German threat, according to this faction, represented the most immediate concern and needed to be a priority. On the other side were those who, for various reasons, opposed this policy. This group was quite heterogeneous. First Lord of the Admiralty Sir Bolton EyresMonsell did not like the idea of withdrawing all British naval forces from East Asia in order to concentrate on Europe; he argued that a strong naval presence in the East was necessary for the British Empire to maintain its status as a world power. Sir John Simon, who served as foreign secretary for a relatively long stretch, from I93 I to I935, feared Japan's aggressive policies and therefore insisted on keeping good relations with China, all the while nurturing ties with Japan. The head of

${ }^{29}$ Frank Dikötter recently pointed out how the Nanjing decade was a time of "open governance," "open borders," "open minds," and "open markets" in all realms of economic, social, cultural, and political activity. See Frank Dikötter, The Age of Openness: China before Mao (Berkeley: University of California Press, 2008).

30 As Warren Cohen pointed out, in this period "the Chinese perceived, as never before, the uses of art as a diplomatic tool." Cohen, East Asian Art and American Culture, I04. See also John Fitzgerald, Awakening China: Politics, Culture, and Class in the Nationalist Revolution (Stanford, Calif.: Stanford University Press, I996), 53-54. On the importance of "symbols" in Republican China see Henrietta Harrison, The Making of the Republican Citizen: Political Ceremonies and Symbols in China, I9I I-1929 (Oxford: Oxford University Press, 2000). 
the Far Eastern Department of the Foreign Office, Charles W. Orde, also suggested being cautious and avoiding dramatic changes in the existing course. People in this second group found themselves in agreement with the League.

Starting from June 1935, the Chamberlain/treasury faction eventually prevailed, defining British policy for years to follow. At the time the exhibition was organized, however, the Foreign Office was still dominated by the second group. It therefore promoted a policy, which largely coincided with the League's, of keeping good relations with China all the while nurturing ties with Japan. ${ }^{31}$ For this reason, in response to the letter proposing a major Chinese exhibition in London, the Foreign Office insisted that no domestic tensions in China were to be triggered, no political instabilities were to be caused, no issues in bilateral relations with Great Britain were to be raised, and, above all, no anti-Japanese feelings were to be fueled during the process of displaying the culture and politics of Japan's most recent prey. On the contrary, every effort needed to be made to ensure that China (and its government) would be celebrated in an atmosphere of international cooperation, mutual understanding, and goodwill in which everybody - and especially Japan — would be included. ${ }^{32}$

The plan of staging a spectacle of internationalism did not quite unfold as smoothly as both governments had envisioned. In China,

31 Although the secretary of state at the time, John Simon, often vacillated between the two views and the pro-Japanese influence of the treasury over the Foreign Office continued to grow, until mid 1935 the policy of the British Foreign Office remained in line with the League's. It was only after Stanley Baldwin became prime minister and Samuel Hoare took over the post of foreign secretary (on 7 June 1935) that this position shifted. One of Hoare's first acts as foreign secretary was to declare himself in agreement with Neville Chamberlain's philo-Japanese strategy in East Asia. This meant the further withdrawal of support for the League and the encouragement of British unilateral initiatives. As Stephen Endicott illustrated in his work on British-Chinese relations in this period, C. W. Orde thought that "Britain's policy would have to be of an opportunist nature, even though he knew that 'minds naturally ardent, or by predilection systematic' would dislike this view." Stephen Endicott, Diplomacy and Enterprise: British China Policy, 1933-1937 (Manchester: Manchester University Press, 1975), 79.

32 Asked for his opinion about the proposed cultural event, Cecil Harcourt-Smith (who served as surveyor of the royal works of art and as British representative in the League's International Museum Office) replied by pointing out the tension (or, in Cecil's words, the "court struggle") between the museum authorities in Beijing/Beiping and the Nanjing government over where Chinese artifacts were to be housed. He also recommended that the British Foreign Office not "play into the hands" of one side or the other, and that the organizers not push too hard to obtain the consent of the Chinese government. $\mathrm{FO}_{370 / 452}, \mathrm{~L}_{308} / 308 / 405$. Handwritten comments by Cecil Harcourt Smith, dated I9 January I934. 
the Nanjing government's decision to accept the invitation from Great Britain was attacked from multiple fronts. First, the authorities of the Beijing palace were reluctant to hand over their objects to Nanjing. Second, only a few days after the plans for the exhibition were announced, a group of intellectuals issued a "manifesto" protesting Chinese participation. Allowing a British committee to pick objects meant that the Chinese were "abdicating" their rights over their own treasures. More importantly, Chinese intellectuals warned, "once an object of art is acquired by the British Museum, it will never be allowed to leave its portals, whatever may be its value." Another article published by the Chinese press supported the arguzments expressed in the "manifesto": if China could not (I) select the objects itself, (2) withhold the most precious, and (3) insure the ones chosen for shipment, then it should not participate in the London exhibition. Many in China argued that these principles should be met, even if this stance cost China the opportunity to exercise "diplomatic courtesy" or to improve its "diplomatic position." 33

The British Foreign Office offered help to counter some of these arguments. On I5 November I934, the secretary of state, Sir John Simon, wrote to the first lord of the admiralty, Sir Bolton EyresMonsell, asking to arrange for the transport of the Chinese artifacts to London. It is important to note that Simon did not merely request the protection of the objects but asked that the navy take charge of it in a conspicuous fashion. "What is desired," the foreign secretary wrote, "is that something should be done which would show how greatly His Majesty's Government appreciate the carrying out of this proposal and how sincere is their wish to contribute in any way they can to carry the scheme through successfully and without untoward incident." For this reason, he asked for a British "ship of war" to sail "in the vicinity" of a "mailship" containing the objects. The idea, he pointed out, came from the Chinese government, which sought to assuage Chinese public opinion with demonstrable reassurances. ${ }^{34}$

Simon explained that although a warship "does not add to the security of these treasures," it should make the Chinese public feel "con-

${ }^{33} \mathrm{FO} 370 / 477$, L 198/198/405. The British Foreign Office collected newspaper clippings and investigated this case. See for instance extract from Peiping Chronicle, 25 January 1935. See also RAA/SEC/24/25/I. Newspaper clipping from Peiping Chronicle, 22 January 1935 .

${ }^{34} \mathrm{FO}_{370 / 452}$, L 6779/308/405. Letter, dated I 5 November I934, from John Simon to Bolton Eyres-Monsell. 
siderably relieved." 35 The following day, the admiralty guaranteed that there would be "no difficulty" in implementing a visible spectacle of safety and security for this occasion. Certainly, the British knew well the importance of spectacles and public displays, since the British Empire itself relied heavily on them to assert and maintain its own power. This gesture, although functionally useless for protecting the artifacts, would display more concern for China and its priceless history than any legal and financial commitment or any insurance policy could ever do. Moreover, it would serve as a visible endorsement of the internationalist policy pursued by both governments at the time. ${ }^{36}$

\section{An Open Exhibition of Internationalism}

According to script, the Chinese works of art made a majestic entry. On 25 July i 935, H.M.S. Suffolk approached Portsmouth harbor. The 630-foot-long County-class heavy cruiser of the Royal Navy carried the priceless cargo of more than eight hundred artifacts that the Chinese government was lending to the 1935-1936 International Exhibition of Chinese Art. ${ }^{37}$ Its grandiose arrival represented only the beginning of a long, elaborate ceremony, one in which a vessel of war was put in the service of international cooperation. As the press highlighted in countless articles, all precautions had been taken to ensure the safety of the artifacts on their long journey. The Chinese works of art had been packed in ninety-three cases lined with steel and then loaded on an "ironclad treasure-ship." As the Star emphatically pointed out, "No force, no looting was necessary, in order to take them from the Forbidden City, and the Suffolk, proudly flying the White Ensign, is anything but a modern pirate ship." 38 While in the past many British subjects had brought back Chinese works of art without paying for them, this time the situation was different: The objects had been willingly loaned by the Chinese government for the specific purpose of being displayed in a temporary exhibition. Great Britain and China had inaugurated a new kind of relationship, one that was amicable and conducted on

35 Ibid.

${ }^{36}$ FO 370/452, L 6779/308/405. Letter, dated i6 November 1934, from Bolton EyresMonsell to John Simon.

${ }^{37}$ In the end, the artifacts were placed on a County-class heavy cruiser of the Royal Navy, H.M.S. Suffolk, with no other ship involved.

38 Star, I2 July I 935. 
equal terms: The treasures had been merely loaned, and the British government would eventually return them.

As the press widely reported, hundreds of people-mostly womenhad gathered to welcome the sailors that had been at sea for more than two years. ${ }^{39}$ The presence of dignitaries and the slow, calculated pace of these procedures added to the solemnity of the moment. The unloading of the ship was a spectacle in itself and was extensively covered by the media. ${ }^{40}$ Everybody's eyes at this point were on the British "bluejackets," who were stretching out their arms to catch each case as it was unloaded, and then parading each one of them in front of the many people that had assembled to watch the scene. Four special delivery vehicles transported the treasures on the last leg of their long journey, from Portsmouth to London. All of the chief constables had been alerted and an escort accompanied the extraordinary caravan. The following morning, as one newspaper reported, "The great I $8 \mathrm{ft}$. high wrought iron gates at the Piccadilly entrance to Burlington House were locked, barred and bolted ... Within those gates in the courtyard were four ordinary vans. They contained priceless treasures of the Orient." 41

A British and a Chinese member of the committee inspected each case as it was unloaded (Fig. I). The jet-black cases themselves, along with "HANDLE WITH CARE" written in English in white capital letters, expressed the great caution with which they were handled. A crowd of spectators amassed to take in the meticulous labor of these men. No doubt, the crowd watching the scene unfolding in the academy's courtyard was much larger than the one in the galleries. ${ }^{42} \mathrm{~A}$ few weeks later, when the steel-lined cases containing the artifacts from China

39 Starting from I934, the Royal Academy of Art hired Alleyne Clarice Zander to act as a "publicity agent." Zander began a press-cutting archive of all the exhibitions held at the Royal Academy. The press coverage of the Chinese exhibition was particularly extensive, and I thank the archivist of the academy, Mr. Mark Pomeroy, who kindly allowed me to access this archive when it was still in the process of being preserved and catalogued.

40 See, for instance, Universal News, "Warship's Art Cargo," issue no. 527, item 9/I I, released on 29 July 1935 .

${ }_{41}$ Liverpool Evening Express, July 26, 1935.

42 The Nottingham Journal commented: "Artists exhibiting at this year's Academy must wish that the great consignment of Chinese treasures which were put into the vaults this morning had arrived a month later... In the excitement aroused by the forthcoming Winter Exhibition both sales and attendances at Burlington House have slumped and to-day it was the Chinese treasures at the side entrance rather than the English pictures which will hang until ro August that were attracting attention" [underlining in the original]. Nottingham Journal, 27 July 1935. The same article was also published in Northern Echo and in Darlington. 


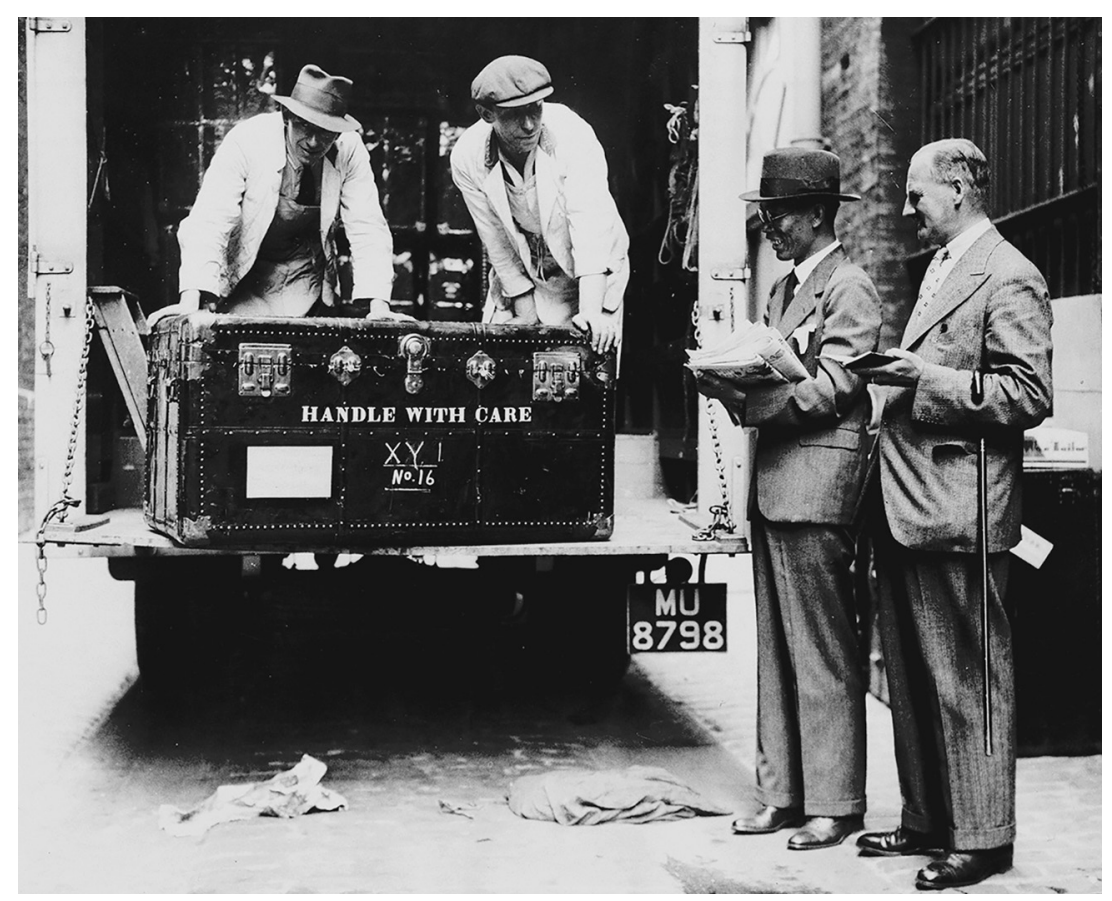

Figure I. Sir Walter Lamb and Zhuang Shangyan (Chuang Shang-yen) checking cases as they arrive at Burlington House. (The International Exhibition of Chinese Art at the Royal Academy, I935-1936. Photograph by an unknown photographer working for the Topical Press Agency, I935. Black and white silver gelatin print, $193 \times 246$ millimeters. (C) Royal Academy of Arts, London.)

were opened and the treasures revealed, newsreels showed British and Chinese members of the exhibition's organizing committees working together, unpacking each object, slowly removing the multiple layers of packaging, and proudly holding the precious contents. Pictures were taken and published throughout this process (Fig. 2). Even before the doors of Burlington House had opened to the public, the internationalist spectacle had already begun.

The unprecedented collaboration among individuals, institutions, and governments from various countries around the world constituted the most important feature of the 1935-1936 International Exhibition of Chinese Art in London, and was publicized as such. The official exhibition catalog opened with a long list of patrons, honorary presi- 


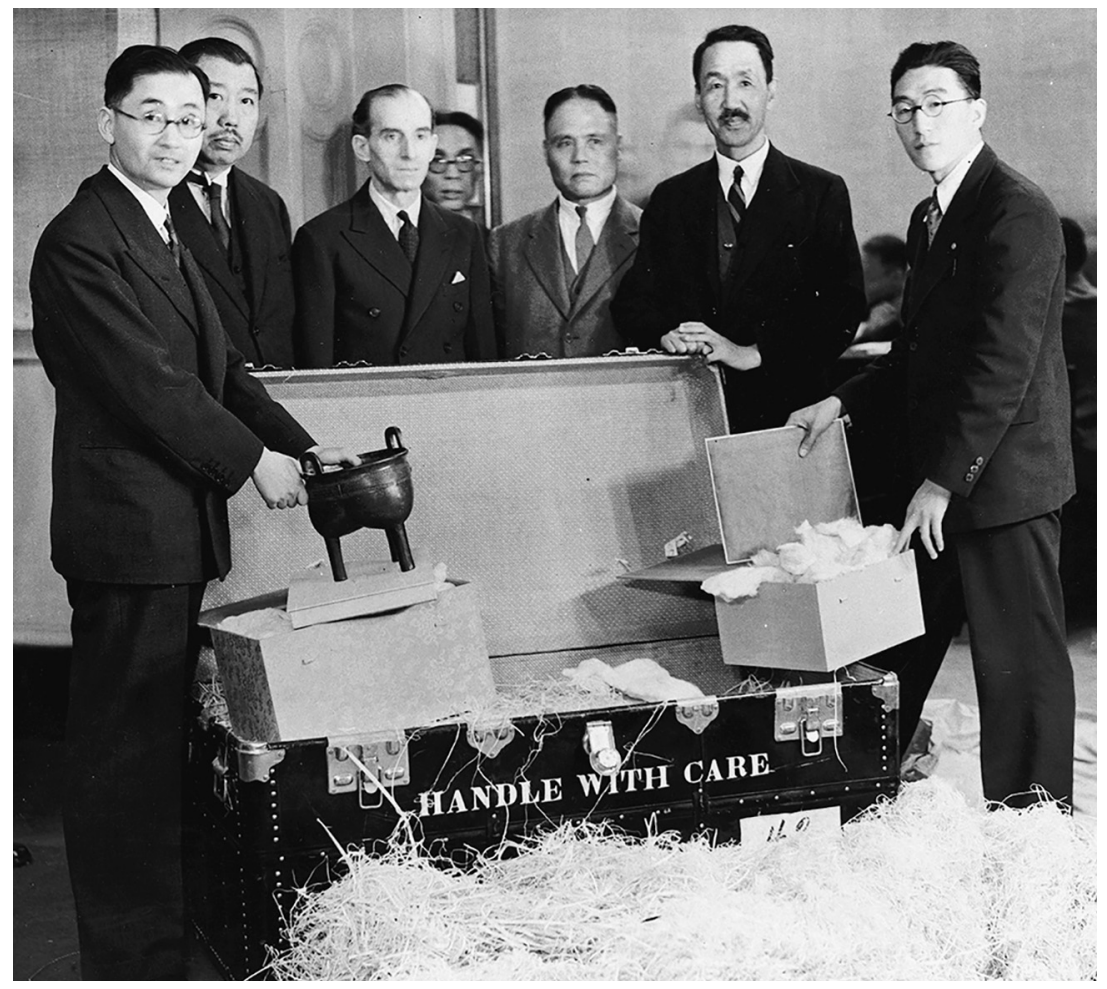

Figure 2. From left to right: Zhuang Shangyan (holding a black cauldron), Dr. Zheng Tianxi (F.T. Cheng), Special Commissioner of the Chinese Government, Sir Percival David, Exhibitor Director, and on the other side (resting his hands on the case lid at the corner) is Tang Xifen, Exhibition Secretary. (The International Exhibition of Chinese Art at the Royal Academy, I9351936. Photograph by an unknown photographer working for the Topical Press Agency, I935. Black and white silver gelatin print. I97 × 25I millimeters. (c) Royal Academy of Arts, London.)

dents, and committee members. ${ }^{43}$ The preface, written by the British diplomat Lord Victor Bulwer-Lytton and the president of the Royal Academy, William Llewellyn, presented the Chinese exhibition as being first and foremost an international event made possible by the "willing support of the Chinese Government" and by the matching

${ }^{43}$ Catalogue of the International Exhibition of Chinese Art, I935-1936, vi-x. 
assistance of His Majesty's government. It also proudly listed all of the countries that had lent artifacts for the exhibition: Austria, Egypt, France, Sweden, Turkey, the Soviet Union, the United States, Germany, the city of Danzig, and Japan. In the midst of international tensions, it was significant that this roster included nonmember states of the League of Nations (such as the United States) as well as countries (such as Germany and Japan) that between I 935 and I936 were challenging the League and the international system as a whole.

Much emphasis was placed on the involvement of Japan. Japan figured prominently on the list of lenders, as a few Japanese collectors agreed to send some of their pieces. This was not a coincidence. The exhibition organizers, the British Foreign Office, and especially the British ambassador in Tokyo, R. H. Clive, pulled all the strings they could to make this happen. ${ }^{44}$ As well, the exhibition director, Percival David, traveled to Japan and promised an exhibition of Japanese art in London to take place in the near future. ${ }^{45}$ In the end, loans were

44 On I January I935, Foreign Office librarian Stephen Gaselee wrote to the Japanese ambassador in London, Tsuneo Matsudaira, asking for support. The organizers were soon to meet members of the Japanese government, and the British secretary of state wished the project "to be assisted by all means in our power." FO 370/452, L 7491/308/405. Letter, dated I January 1935, from Stephen Gaselee to Tsuneo Matsudaira. According to the minutes of the Royal Academy, the Japanese ambassador promised his assistance in securing these loans. RAA/PC/6/13/2. Royal Academy Handwritten Minutes, Meeting 7 January 1935. He then contacted the British ambassador in China, Alexander Cadogan, and the ambassador in Tokyo, asking the latter to "mention the matter semi-officially to the Japanese government." See FO 370/477, L i 98/1 98/405. Letter, dated I I January I 935, from Stephen Gaselee to Walter Lamb. From Tokyo, British ambassador Robert Clive wrote about the many difficulties he encountered. FO 370/477, L 3040/198/405. Letter, dated 8 April I935, from Robert Clive to Stephen Gaselee and FO 370/477, L 3040/198/405. Letter, dated 5 April 1935, from Robert Clive to Oscar Raphael. On 29 May 1935 the Times announced that the committee's request for loans had been denied. Times, 29 May I935. FO 370/477, L 3040/198/405. Newspaper clipping. Unexpectedly, in late August 1935, after most loans from other countries had been finalized, a cablegram, dispatched from Osaka on 2 I August I 935 and received in London two days later, brought the news of Japan's official participation in the 1935-1936 International Exhibition of Chinese Art in London. The sender (the prominent art dealer Sadajiro Yamanaka) heartily rejoiced at this success FO 370/477, L 5632/198/405. Cablegram, dated 21 August 1935, from Sadajiro Yamanaka to Percival David (?). As Percival David (the probable recipient) acknowledged soon afterward, this accomplishment was due largely to British ambassador Robert Clive and to Stephen Gaselee of the British Foreign Office. FO 370/477, L 5632/198/405. Letter, dated 23 August 1935, from Percival David to Stephen Gaselee.

45 On the proposed exhibition of Japanese Art in London see FO 395/536, P 39/39/I 50. Copy of a letter, dated io December I935, from Colonel Bridge (British Council) to Lord Riverdale of Sheffield giving an account of an interview with Baron Ino Dan on the subject of Anglo-Japanese cultural relations. Baron Ino Dan mentioned the possibility of an exhibition of Japanese Art in London to follow the Chinese one; he also mentioned Percival David, with whom "he has already discussed the matter." 
sent from the imperial household, the Imperial Household Museum in Tokyo, the Tokyo Fine Arts School, and the Kyoto Imperial University, as well as from several Japanese private collectors. More importantly, thanks to these contributions, Japan was included in the list of participating countries.

In addition, a Japanese lecturer was included in the program. ${ }^{46}$ On Io January I936, Japanese professor Yukio Yashiro gave a talk on Chinese paintings. The active participation of a scholar from Japan raised hopes that the exhibition could play a role in the peace-building process. In providing comments on Yashiro's lecture, the Daily Telegraph published a piece titled "Sino-Japanese Entente" (a rare occurrence in the headlines at the time). The article pointed out the contrast between "the presence last night of a Japanese lecturer at the Chinese Art Exhibition" and the fact that "in North China the presence of Japan makes for a delicate situation." And yet, the article also emphasized that the Japanese representative, who had been sent by the Society for International Cultural Relations of Japan, had been enthusiastically welcomed by all people involved in the 1935-1936 International Exhibition of Chinese Art. The title itself-"SinoJapanese Entente"-suggested that optimism in London increased hopes for the improvement of the political situation abroad. At least within the confines of Burlington House, international cooperation was a reality. ${ }^{47}$

The most explicit reference to internationalism (and to the institution that best embodied it in this period-the League of Nations) was the choice of Lord Lytton as the honorary chairman for the exhibition. ${ }^{48}$ A character often mentioned but rarely analyzed in depth in current literature, Lytton enjoyed worldwide notoriety in the I93os.

46 The lecture program was very successful. The academy's 1935 annual report remarked that "So great was the interest of the public that, besides the many lectures arranged throughout the country, two series of official lectures were given in the rooms of the Royal Society, and all of them were crowded." Annual Report from the Council of the Royal Academy to the General Assembly of Academicians and Associates for the Year 1935 (London: William Clowes and Sons, I936), 23. A full list of the lecture program can be found in the Catalogue of the International Exhibition of Chinese Art, 1935-6 (London: Royal Academy of Arts, 1935), xi-xii.

47 Daily Telegraph, I I January 1936.

48 Although his name appears in any survey of international history in the context of the Manchurian crisis, there is no published biography of Lord Victor Bulwer-Lytton. An unpublished account of his life, written by his son-in-law C. M. Woodhouse, is held at the archive of the historical Lytton residence, Knebworth House, in Hertfordshire. C. M. Woodhouse, A Biography of Victor Lytton, Second Earl of Lytton (unpublished). 
After Chinese and Japanese troops clashed along a railway line in the Manchurian town of Mukden on I 8 September I93I, the League of Nations appointed a commission, headed by Lytton, to investigate the responsibility for this event as well as for the subsequent occupation of Manchuria by Japanese forces. ${ }^{49}$ What became known as the "Lytton Report" was adopted by the League Council on 24 February I933, and established that the Mukden incident had been initiated by the Japanese; at the same time, it traced the long history of Japan's "special position" in Manchuria, and reasserted the legitimacy of Japanese economic "rights" in the region..$^{50}$ This document became an example of how attempts at reconciling two parties could lead to the dissatisfaction of both: In historical surveys of this period, it is often mentioned as the first serious blow to the authority of the League. Due to its conciliatory nature, the Lytton Report has also been described as a step along the inevitable path toward "appeasement" and as the beginning of the descent into World War II. ${ }^{51}$

Lord Lytton, however, would have disagreed with this interpretation. In fact, in the period between 1932 and the outbreak of World War II, he devoted much of his energies to trying to prove the opposite point. In the years following the Manchurian crisis, Lytton wrote, spoke, and rallied indefatigably in support of the League. In a series of pamphlets and lectures, he discussed his experience in Manchuria and argued against the inevitability of failure for the League of Nations. As

${ }^{49}$ Much has been written about the "Manchurian crisis." The most detailed account remains Westel Willoughby, The Sino-Japanese Controversy and the League of Nations (New York: Greenwood Press, I968; Ist ed., Baltimore: John Hopkins Press, I935).

50 The report therefore recommended that the League guarantee both the Chinese political control of Manchuria and the protection of foreign (including Japanese) interests in the area. Foreign advisers would safeguard the rights of both parties through ample use of political conciliation and legal arbitration in order to facilitate peace and stability in the region. The commission's plan never came to fruition since as a result of this assessment Japan left the League of Nations. In the following years, Japan continued to extend its military control of Chinese territory, and the League did not intervene militarily to stop this advance.

${ }^{51}$ One of the first works to argue that the Manchurian crisis led inevitably to another war is Sara R. Smith, The Manchurian Crisis, I 93 I-1932: A Tragedy in International Relations (New York: Columbia University Press, I948). For a judicious account and a recent bibliography on these events, see Thomas Burkman, Japan and the League of Nations: Empire and World Order, I9I4-1938 (Honolulu: University of Hawai'i Press, 2008). For a revisionist view, see Rana Mitter, The Manchurian Myth: Nationalism, Resistance, and Collaboration in Modern China (Berkeley: University of California Press, 2000); Prasenjit Duara, Sovereignty and Authenticity: Manchukuo and the East Asian Modern (Lanham, Md.: Rowman and Littlefield Publishers, 2003); and Mariko Asano Tamanoi, ed., Crossed Histories: Manchuria in the Age of Empire (Honolulu: University of Hawai'i Press, 2005). 
vice chairman (I935-I938) and later chairman (I938-I945) of the League of Nations Union, he encouraged his government not to act unilaterally but to continue to strengthen its support for international bodies. For the rest of his life, he remained steadfast in his belief that world peace could be achieved through international cooperation. ${ }^{52}$

In a climate of growing tensions and anxiety, few openly agreed with him. Yet, among his supporters - and among the harshest critics of Chamberlain's policies-were several of the people involved in the 1935-1936 International Exhibition of Chinese Art. In 1937, Sir Percival David and George Eumorfopoulos became active in the China Campaign Committee, an organization that vehemently denounced the Japanese aggression toward China, Chamberlain's philo-Japanese strategy, and the inaction of the international community in this context. ${ }^{53}$ Commissioner of Works William Ormsby-Gore, who played an important part in providing governmental "auspices" and approval for the exhibition, later offered his resignation to Prime Minister Neville Chamberlain in protest of his policies. ${ }^{54}$ And Lord Lytton himself was one of the most vocal of Chamberlain's critics. As historian Cecilia Lynch pointed out, many members of internationalist organizations who were later "blamed" for appeasement in reality had been very active in opposing it. After the signing of the I938 Munich Agreement in particular, their reaction "ranged from unease to condemnation." ${ }^{55}$ Although some of these developments followed the I935-1936 exhibition and therefore cannot be used to explain it, it is safe to say that Lord Lytton was the most recognizable figure associated with this cultural event, one that openly celebrated the internationalist policies and ideals that - for better or worse-he had pursued for a lifetime. It was in this light that he served as the chairman and the symbol of the r935-r936 International Exhibition of Chinese Art, an event in which Chinese art was put to work to serve the internationalist cause.

52 The goal of the League of Nations Union was to promote and to popularize support for the League of Nations and for its ideals.

53 On Percival David and his involvement in the China Campaign Committee, see Stacey Pierson, "From Market and Exhibition to University: Percival David and the Institutionalization of Chinese Art History in England," in Collecting China: The World, China, and a History of Collecting, ed. Vimalin Rujivacharakul (Newark: University of Delaware Press, 20II), I33.

${ }_{54}$ DNB, s.v. Gore, William George Arthur Ormsby-, fourth Baron Harlech (I $88_{5-}^{-}$ I964). On his involvement in the exhibition, see $\mathrm{FO} 370 / 452$, L 6779/308/40. Letter, dated 29 November 1934, from John Simon to William Ormsby-Gore.

55 Cecelia Lynch, Beyond Appeasement: Interpreting Interwar Peace Movements in World Politics (Ithaca, N.Y.: Cornell University Press, I999), I I 9. 


\section{Chinese Art and the Aesthetics of Internationalism}

The established orientalist paradigm, which so far has dominated nearly every discussion of China in the political and cultural landscape of the twentieth century, does not suffice to explain the role played by Chinese art and culture in both disseminating and shaping internationalist ideas and practices in the I93os. The notion that works of art could serve a political purpose (or that "artifacts are agents in the present," to borrow an expression by Ellen Huang) ${ }^{56}$ was not limited to those produced by the Chinese; in fact this very idea informed the policies of the Committee of Intellectual Cooperation of the League of Nations (especially initiatives such as exchanges of archives and artifacts) and the work of institutions such as the International Museum Office in all geographical settings. ${ }^{57}$ Similarly, the choice of displaying Chinese "Old Masters" cannot merely be explained by the desire to portray China as "old" and "immutable." In fact, all of the other international exhibitions held at Burlington House in the rg2os and I930s displayed art from previous centuries and avoided contemporary work. At a time when the debate over the value of modern art was most heated in Europe, selecting works by Old Masters who were part of an established aesthetic canon and whose value was therefore undisputed represented the most pragmatic choice.

Furthermore, the idea that art expressed a country's "national" or even "racial" spirit was not confined to the Chinese case or to the postcolonial context. Other "European" exhibitions in this period incorporated into their rhetoric the idea that art would bring out the country's

${ }^{56}$ Huang, "There and Back Again," I 43.

57 After the looting and destruction of artifacts during World War I, and at a time when works of art assumed greater symbolic value as national treasures, the League of Nations (and the International Museum Office in particular) encouraged respect for artifacts and their shelter in wartime and addressed issues of ownership and repatriation. See R. Lévy, "Les beaux-arts dans la vie international," La paix par le droit 4I (April-May I93 I): 2 I I-220. See also Renoliet, L'Unesco oubliée, 3 Io-3 I I. Furthermore, the International Museum Office defined artifacts not only as "national treasures" but also as a "patrimony of humanity" to be devoted to the education and to the enjoyment of the general public. On the broader debate about ownership of artifacts see Kate Fitz Gibbon, ed., Who Owns the Past? Cultural Policy, Cultural Property, and the Law (New Brunswick, N.J.: Rutgers University Press, 2005). For a legal perspective see Anneliese Monden, "Art Objects as Common Heritage of Mankind," Revue belge du droit international I9, no. 2 ( I986): 327-338. For an "internationalist" approach advocating nonrestitution, see John Henry Merryman, ed., Imperialism, Art, and Restitution (New York: Cambridge University Press, 2006). On the implications of considering artifacts a "patrimony of humanity," see Ana Filipa Vrdoljak, International Law, Museums and the Return of Cultural Objects (New York: Cambridge University Press, 2006). 
true national "spirit," but while some interpreted that "spirit" in purely nationalistic terms, others saw it as the expression of a country's willingness to join the international community on peaceful terms. In the case of the I930 Italian Exhibition, for instance, some looked at the magnificent collection that Mussolini and the Fascist regime sent to London as a "a portentous sign of the eternal vitality of the Italian race" $; 8$ others-the majority—saw this enthusiastic participation as proof of the generosity of the Italian government and its willingness to engage in friendly cooperation with other countries. The adjective "Fascist" or the term "dictatorship" rarely appeared in contemporary references to the Italian government. If the I930 exhibition "flaunted" Italy's "national prestige," as Francis Haskell has argued, it did so by presenting Italy as a country that had never been at war against Great Britain. Similarly, in the Chinese case, references to the "racial" and "national" spirit as it was reflected in Chinese art did not emphasize postcolonial discourses of racial difference. Instead, they echoed the principles of "twentieth-century internationalism."

Other aspects, however, made Chinese art and culture fit well the internationalist frame. The first was political. Since the "Wilsonian moment," China had been one of the League's most ardent supporters. ${ }^{59}$ Even after great disappointments, ${ }^{60}$ many in China kept looking to Geneva and to the League of Nations as a possible ground for China to achieve equality in the international arena. ${ }^{61}$ Chiang Kai-shek's policy of "openness," with all of its flaws, fell in line with the League's. Especially after the Manchurian crisis, China had served as a model for all League supporters as it had declined to take matters into its

58 Times, 3 January r930, 9.

59 On the appeal of Wilsonianism in China, see Guoqi Xu, China and the Great War: China's Pursuit of a New National Identity and Internationalization (New York: Cambridge University Press, 2005). For a vivid account of the Chinese experience from the I9I 8 armistice through the negotiations of the Versailles Treaty, see also Paul French, Betrayal in Paris: How the Treaty of Versailles Led to China's Long Revolution (Melbourne, Australia: Penguin Books, 20I4).

60 When clauses to ensure racial equality were debated but ultimately not included, and when the announcement was made that Japan was to inherit German rights in the Chinese province of Shandong (rather than having China recover them), the members of the Chinese delegation were devastated and the dreams of millions were shattered. On the long-term consequences of this disappointment, see Erez Manela, The Wilsonian Moment: Self-Determination and the International Origins of Anticolonial Nationalism (Oxford: Oxford University Press, 2007).

61 On the Chinese "obsession" with achieving full integration in the global community see Xu, China and the Great War, 276. See also Bruce A. Elleman, Wilson and China: A Revised History of the Shandong Question (Armonk, N.Y.: M. E. Sharpe, 2002). 
own hands but had relied instead on the League to solve the issue. Seen against this background, the act of engaging and celebrating the Republic of China was a celebration of the League and its ideals.

Second, the academic fields of Chinese art and Sinology were very international. They consisted of a network of transnational individuals who traveled frequently, worked abroad for lengthy periods of time, often served in international and supranational bodies as either formal or informal representatives of their countries, and therefore had a strong international identity. Most of the European members of the executive committee for the Chinese exhibition had visited China as well as other parts of Asia multiple times. Many of them were archaeologists and collectors who had had plenty of firsthand experience of China and its treasures. As Stacey Pierson pointed out, the director of the exhibition, Sir Percival David, "was not English"; he knew Chinese well and spent much of is life traveling around the world. ${ }^{62}$ As for the Chinese members, most of the Planning and Preparatory Committee had spent months, if not years, abroad. Several in this group had studied in Japan, Europe, or the United States. The chairman of the committee, the minister of education, Wang Shijie, spent considerable time in London, Paris, and the Hague. His close associate, SecretaryGeneral Chu Minyi, went first to Japan, then to France, and later traveled extensively around the world. ${ }^{63}$ Gan Naiguang studied political science at the University of Chicago and also visited Europe. ${ }^{64}$ The vice minister for foreign affairs, Xu Mo, attended George Washington University, while the vice minister for education, Duan Xipeng, was also a student at several institutions abroad, including Columbia University, the University of London, Berlin University, and the University of Paris. ${ }^{65}$ These individuals constituted a new generation of schol-

62 Pierson, "From Market and Exhibition to University," I3 I.

${ }^{63}$ Chu Minyi 褚民谊 (I884-1946) was a close associate of Wang Jingwei's and served under him as secretary-general of the Executive Yuan. See Howard L. Boorman and Richard C. Howard, eds., Biographical Dictionary of Republican China (BDRC) (New York: Columbia University Press, I970), s.v. Ch'u Min-i.

${ }^{64}$ Gan Naiguang 甘乃光 (1897-1956) later served as Chinese ambassador to Australia, where he stayed until his death. See BDRC, s.v. Kan Nai-kuang.

${ }^{65} \mathrm{Xu}$ Mo (Hsü Mo) 徐谟 (1893-1956) was a professor of law and political science and also served as vice minister for foreign affairs. Starting from 1927 , he worked as a judge at the provisional court of the international settlement in Shanghai, which had been established after the Chinese requested the abolition of extraterritoriality. When C. T. Wang was made minister of foreign affairs in 1928, he became his aide and the head of the European and American Affairs department. After r93 I, he shifted to Asian affairs and played a key role in molding Chinese foreign policy. Between I 940 and I 945 he was in Australia, where he spent the rest of his life. See BDRC, s.v. Hsü Mo. On Duan Xipeng 段錫朋 (r 896-I948), see BDRC, s.v. Tuan Hsi-p'eng. 
ars and politicians with a transnational identity, one that had been shaped heavily by their travel and work abroad. ${ }^{66}$ As such, this group epitomized the League's ideal. It was a "League of Minds" made up of experts working across national borders. ${ }^{67}$

Third, but perhaps most important, Chinese art and culture (and especially Chinese philosophy) were seen at the time as expressing values and emotions similar to those associated with internationalism. This was the result of the work of people like Laurence Binyon, who for decades prior to the exhibition had played a major role in educating the European public on Asian art. In his writings, Binyon employed aesthetic criticism as a way to comment on Western society. As biographer John Hatcher pointed out, "Binyon shared the Victorian disgust at the way the capitalist city reduced all relationships to the cash nexus, isolating alienated individuals within their own cocooning private interests." ${ }^{68}$ He thus put forth a widespread critique of the "modern," capitalist world using China as a means to point out its flaws. According to him, China encompassed what Great Britain-and the "modern" world as a whole-seemed to lack: calm, respect for nature, and appreciation for peace. Chinese works of art exuded all of these qualities, and, by studying them and viewing them, he hoped, Europeans might incorporate them into their own worldview. ${ }^{69}$

${ }^{66}$ The first wave of Chinese students going abroad began in the $18705-1880$ s as part of the Qing's attempt to "self-strengthen" the country through Westernization. A second, much stronger wave took place at the beginning of the twentieth century, when thousands of Chinese students traveled to study abroad (mostly to Japan, Europe, and the United States). The great majority returned and served in some governmental position. See Weili Ye, Seeking Modernity in China's Name: Chinese Students in the United States, I900-1927 (Stanford, Calif.: Stanford University Press, 200 I); see also Stacey Bieler, "Patriots" or "Traitors"? A History of American-Educated Chinese Students (Armonk, N.Y.: M. E. Sharpe, 2004). On the experiences abroad of future members of the Communist Party, on the impact of the generational conflict on the movement to study abroad, and on the politicizing effect of travel, see Marilyn A. Levine, The Found Generation: Chinese Communists in Europe during the Twenties (Seattle: University of Washington Press, I993).

67 Intellectual cooperation was supposed to form a "League of Minds" whose ties would extend from the cultural to the political realm. As philosopher Paul Valéry and art historian Henri Focillon explained in the introduction to an open letter published by the Institute of Intellectual Cooperation in I933, if perpetual peace was ever to become a reality a "fundamental agreement" among people of learning in different countries needed to be reached. Paul Valéry and Henri Focillon, "Introduction," in A League of Minds, An International Series of Open Letters, I (Paris: International Institute of Intellectual Cooperation, I933), I 3.

${ }^{68}$ John Hatcher, Laurence Binyon: Poet, Scholar of East and West (Oxford: Clarendon Press, I995), 98.

69 Hatcher noted how Binyon's interest in Asia (and especially his fascination with Taoism) did not constitute a form of "modish spiritual posturing" nor did it provide a means for accumulating fame or material wealth (in fact, his friends often expressed concern for his 
To be sure, a few obstacles were in the way. The influence of Chinese poetry on the rhythmical accord of a Chinese painting might be, at first, hard to grasp. And yet, besides the love of space, the solitude, and the solemnity apparent in Chinese art, "a humorous playfulness and gaiety will unexpectedly show themselves; and behind it all is a genial humanity."70 Similarly, Chinese pottery had the potential to speak a universal language that could be understandable to all people: "appealing to the senses alike of sight and touch the finest of the bowls and vases seem at the same time to transcend the world of sense and to speak in some subtle and secret way to the emotions of the spirit." 71 Chinese art, he contended, communicated directly to the human heart.

Binyon's arguments constituted a new form of orientalism, one that was meant to foster internationalist ideas and practices while correcting the flaws of the "modern" world. His was a self-reflective representation of "the other," meant to make European peoples and powers question themselves, their policies, and their attitudes. Binyon's vision, like internationalism, included nationalistic and imperialistic aspects, yet defined itself as very much distinct from and often antagonistic to both imperialist and nationalist policies. Indeed, his vision implied a fundamental disagreement with the "modern"—and "Western"-economic and political systems as well as contempt for what he saw as a widespread lack of moral values in the "West." Binyon's orientalism also included a pragmatic element: To him, ideas about China and its culture, and the practice of exchanging and admiring them, constituted the first step to building peace. During a formal luncheon in honor of the Chinese art exhibition, he emphasized how European portraits reflected excessive individualism and greed, while Chinese landscapes emphasized the majesty of nature and expressed "a completer vision of life, a vision in which there is no room for our small greed and self-aggrandizement." Although Binyon never mentioned the word "peace," his toast extolled the positive effects that Chinese art could have on the larger project of countering the negative effects of capitalism and "modernity" and therefore of maintaining peaceful relations among nations. ${ }^{72}$

and his family's well-being). Instead they were the expression of a man's search for a deeper understanding of himself, his own society, and the complexities of the "modern" world in which he lived. Hatcher, Laurence Binyon, I34.

${ }_{70}$ Laurence Binyon, "Introduction," in Catalogue of the International Exhibition of Chinese Art, 1935-1936, xv.

71 Ibid., xvii.

72 "Luncheon in Honour of the Chinese Art Exhibition," Journal of the Royal Central Asian Society 23 (January 1936): 96. 
Binyon's ideas were shared also by the Chinese ambassador in London, Guo Taiqi. At the same luncheon, he remarked:

It is not in the themes of war and battle that the emotion of the Chinese artist finds expression, but on the contrary he derives his inspiration from the love of humanity, the contemplation of Nature, and an understanding of man's place in the universe. The ideal of peace and virtue is one which China upholds persistently, even in the darkest hours of her national history.

Guo was confident that all who took in the galleries of Burlington House would be convinced that "the Chinese are fundamentally pacific people." ${ }^{73}$ Chinese art would therefore form an emotional bond among individuals from different countries, one that was based on a shared longing for peace. It would trigger a set of feelings that would foster peace and turn the world into an internationalist "emotional community." 74

F. T. Cheng, who served as the special commissioner of the Chinese government for the Chinese exhibition, also gave an address on the multiple ways in which Chinese culture and art fostered peace and international cooperation. He perhaps expressed best how Chinese art-with its aesthetic and emotional core-could contribute to world peace. In a lecture delivered at the London Royal Academy on 6 December 1935, he explained that Chinese art, because of its capacity to calm the mind and unite people, could serve as a powerful tool of governance. He then stressed how peace and harmony were engrained in Chinese cultural history: Chinese art was "not created by the bayonet, but produced by the desire of those things which make perfect beauty: peace, virtue, righteousness, and love." If applied on an international scale, these "things which make perfect beauty" could also bring about peace. ${ }^{75}$ As Welsh author Arthur Machen pointed out

${ }^{73}$ Ibid.

74 Rosenwein's concept of "emotional communities" to define "groups in which people adhere to the same norms of emotional expression and value-or devalue-the same or related emotions" is useful here to capture the elements of "experience" and "feeling" that played an important part in providing support to the League of Nations as an institution and to internationalism as a movement in the I920s and I930s. See Barbara H. Rosenwein, Emotional Communities in the Early Middle Ages (Ithaca, N.Y.: Cornell University Press, 2006), 2.

${ }^{75}$ F. T. Cheng, "Some Cultural and Historical Aspects of Chinese Art," delivered at the London Royal Academy on 6 December 1935, in Cheng, Reflections at Eighty (London: Luzac and Co. Ltd., I966), 70. 
when Cheng's lectures were published, his references to "peace, virtue, righteousness, and love" assumed even greater significance "in the London of I 936." This was a place where "we talk a good deal about peace, to be sure, but usually in connection with some furious propaganda, calculated to end in a frightful war," and where virtue, righteousness, and love were rarely mentioned. ${ }^{76}$ This association between Chinese art and peace, and especially the emotions it evoked, represented the strongest endorsement of internationalism and of the feelings that had fueled it since its inception.

\section{Conclusion}

In April 1936, the Chinese works of art shown at the 1935-1936 international exhibition left London's George V Dock to embark on their long journey back to Shanghai. There was no ceremony to accompany their departure, no naval escort to ensure their safe return home. ${ }^{77}$ The responsibility fell exclusively on the S.S. Ranpura, one of the commercial liners of the Peninsular and Oriental Steam Navigation Company. On I4 April, shocking news broke: Due to rough seas, the ship had run aground and was stuck northwest of Gibraltar. The same newspapers that had once described in detail the careful handling of the Chinese treasures during their trip to Great Britain and throughout the period of the exhibition now discussed how the same treasures could be lost forever. ${ }^{78}$ If the voyage these objects had taken in July I 935 had conveyed a sense of mutual respect, collaboration, and hope, the current state of the Chinese treasures portended the bleakest of prospects. Finally, a sigh of relief came. On i 7 April, the ship was refloated with its cargo undamaged. The next day, as sched-

76 Arthur Machen, "Note," in F. T. Cheng, Civilization and Art of China, Lectures (London: William Clowes and Sons, r936), 3-5.

77 On i9 February 1936, at a meeting of the executive committee of the Chinese exhibition, the Chinese ambassador said that he had been informed by the foreign secretary that the Admiralty might not provide an escort. RAA/PC/6/13/2. Handwritten minutes, I9 February I936 (ff. I05-IO6). Changes in personnel at the Foreign Office after June I935, when Samuel Hoare took office, might explain this decision. Unfortunately the FO files relating to this matter have not survived ( $\mathrm{L}_{506 / 506 / 405}$, listed in the index for 1936 , cannot be located in Box 370/510).

78 See, for instance, The Evening News and Southern Daily Mail of Portsmouth (Hampshire), I4 April I936, 7; Daily Sketch, I 5 April I936; Evening News and Southern Daily Mail, Portsmouth (Hampshire), is April i936, I4. 
uled, it reached Marseille. One month later, on I 7 May I936, at 6:20 a.m., the S.S. Ranpura arrived in Shanghai, and the works of art were returned to their owner, the Ministry of Education of the Chinese government. The show that had begun several months earlier finally drew to a close.

The Peninsular and Oriental Steam Navigation Company downplayed the accident that had endangered the Chinese treasures: After all, the cargo had been delivered to Shanghai on time. ${ }^{79}$ The Annual Report of the Royal Academy also devoted only a few words to the Gibraltar accident. ${ }^{80}$ The only person who, many years later, seemed to remember the drama of those days was the special commissioner of the Chinese government for the Chinese exhibition, F. T. Cheng. In the preamble to a I 966 reprint of the series of lectures that he had delivered on the occasion of the I935-1936 Chinese exhibition, he referred to the incident as one that "caused a host of rumours in China and of course much embarrassment to me." Cheng ended his recollection on a positive note: "Fortunately, the ship was ultimately out of danger and the treasures were safely back in China without a crack." In the end, even in Cheng's account, the story of the 1935-1936 International Exhibition of Chinese Art was a positive one: He had participated in the staging of the greatest exhibition of Chinese art ever mounted in Europe, an event made possible by unprecedented international collaboration and one that after I 945 would serve as a model for other events designed to improve relations among peoples and nations once again scarred by wars. ${ }^{81}$

The aesthetics of internationalism proved to be long lasting. The images associated with the 1935-1936 Chinese exhibition and the emotions they triggered survived the long and bloody Sino-Japanese conflict and World War II. To this day, they define international cooperation in many of its manifestations. The ideology to which they were attached, however, has dissipated along the way. To borrow Sluga's words, it is now part of "the world we have lost," one that was based on assumptions (about racial difference and imperialism, for instance) that have since been questioned. ${ }^{82}$ This study sheds light

\footnotetext{
79 RAA/SEC/24/25/6. Letter, dated I6 June 1936, from the Peninsular and Oriental Steam Navigation Company to the secretary of the London Royal Academy.

80 Annual Report for the Year 1936, 25.

${ }^{81}$ Cheng, Reflections at Eighty, 45.

82 Sluga, Internationalism in the Age of Nationalism, I 50.
} 
on that world by exploring its languages, its images, its emotions, and its aesthetics, which were made not only of works of art but also of the ideas, institutions, and people that led to their preservation and display.

The study of the aesthetics of internationalism, in all its breadth, could grow to constitute a field of its own. Further research is needed to explore the powers at play, especially in cases where aesthetic representations were the result of collaboration among a very diverse group of state and non-state actors. The 1935-1936 Chinese exhibition at times resembled a movie with a reticent director, or a play whose script, set, and music were negotiated in contradictory ways. After the transnational turn, further debate is needed to assess the relative weight of the multiplicity of actors involved in such complex events. Historians of world history who have pioneered the study of people acting across national borders might be best equipped to answer these questions. This exploration of the 1935-1936 International Exhibition of Chinese Art also touches on many themes dear to them, from cultural exchanges and globalization; to the movement of objects, peoples, and ideas across borders; to the comparative and the connective aspects of historical developments. ${ }^{83}$ It also sheds light on areas that have so far received less attention from them, such as the development of internationalism as an ideology and the League of Nations as an institution, and their impact on how people envisioned and made the world a global entity in the interwar period. The result is a complicated picture, one in which universalisms coexisted with assumptions about national difference, one in which individuals and institutions held multiple allegiances at times in contradiction with one another, and one that forces us to go beyond "positive" or "negative" labels to seek more nuanced explanations for this troubled period of history. World historians, who by definition long to capture the breadth of the forest, might find this work useful as yet another step to further explore its depth.

The moment that so many tried to capture in March 1936, as the exhibition was drawing to a close, was a highly emotional one, as it represented a point in time when the aesthetic experience of Chinese

${ }^{83}$ For a bird's-eye view of world history as a field see Jerry H. Bentley, ed., The Oxford Handbook of World History (Oxford: Oxford University Press, 20 I I). On conceptual and methodological issues, see also Douglas Northrop, ed., A Companion to World History (Chichester, U.K.: Wiley-Blackwell, 2012). 
art had turned internationalism from a utopia to a concrete and visible reality. As we learn more about how emotions affect historical developments, the 1935-1936 International Exhibition of Chinese Art surely stands out as an essential chapter in the history of internationalism, illuminating the relationship between politics and aesthetics and the place of China in shaping the political and cultural landscape of the twentieth century. ${ }^{84}$

${ }^{84}$ On the field of history of emotions, see "AHR Conversation: The Historical Study of Emotions," American Historical Review I I 7, no. 5 (2012): I 487-I53 I. See also Barbara H. Rosenwein, "Worrying about Emotions in History," American Historical Review I07, no. 3 (2002): 82 I -845 . 
Copyright of Journal of World History is the property of University of Hawaii Press and its content may not be copied or emailed to multiple sites or posted to a listserv without the copyright holder's express written permission. However, users may print, download, or email articles for individual use. 